\title{
雑 感
}

山口格*

2 月に入ってこの春卒業していく, 若い人たちの椧交を読むのに追わ れているところに，原稿の締切りが迫ったからと事務局の方から警告が 発せられ，日頃のなまけぐせの報いとあわてて書き始めたこの小文が読 者諸氏の特目にとをるのは春を迎光, 大学の研究室でも, 会社でも新し く入った人たちのテーマが決をるころと思われる。

日本を取り巻く国際的状沉が大きく変わり，むた国内に打いて子，と もかく経済的炕大きく発展をした現実をふ委克て，これからの日本はこ らあら枚代なら始といらことが日々論ぜられている。われわれの生きる 化学々その工業の分野でもいろいら観点から考学るべきことが多い。 私自身, 大学の工学部にあって, これからの教育と研究に対して模索の 毎日を送っている。

化学工業といらすのが——極端ないい方をすれば——原子力工業に象 徵されるような純理論から生れたものではなく、いわば生活の知惠的発 想から出発した部分が多く, 近代的工場の中飞括いてすら，いわゆる学 間としての化学と，化学工業の間汇端的に表現でき呚何かが喛然と存在 している現在, 大学に扔いて純学間的立場をとる理学的研究と, 工業を 常に意識して研究をしていく工学的研究と, そして直接企業内の研究と の間注は，并れぞれの特色がなな战発揮されるべきではなかららか。

だんだんスケールの小さくなっていく, 日本の大学の研究, 一品料理 的なものが多く，堂々たるフルコースのメニューに和めにかかる機会が 少ない。企業でる安易な技術導入の時代が終わり, 一企業ではごらにる なら奴問題る多い之思われる。それぞれの特色を生か守研究を遂行する ためには, 制度的にも, 経済的にも困難は多いが, それは先れ乾坤一 擲, 取り組みたいものである。

比較的古い時代に源を発している化学工業のなか炕は，おのずとでき てきた一つの考光为，枠があり，それ合うように一つのプロセス，一 つのオペレーションが出現する。あるい㤝をの逆で，プロセスなり，オ ペレーションが少しずつ枠をつくってきたのかもしれない。枠の中に住 むとなかなか外の世界が見光にくい。枠をつくるのに大い炕寄与した50 年, 100 年前の将光方は, 現在でもず゙らしいものもあららが，桦から

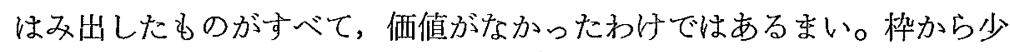
しでもいいから身をずらして間題をとら光たいと念願している。

国境のない学間の世界と，国境の存在する工業との間のぞの位置に， 自分がかかわりあいを持っているのか，はっきり認識していきたいるの である。

* Tadashi Y YMAGUCHI 東北大学（工学部応用化学科.980 宮城紧仙台市 荒巻字青葉）教授・工博 